
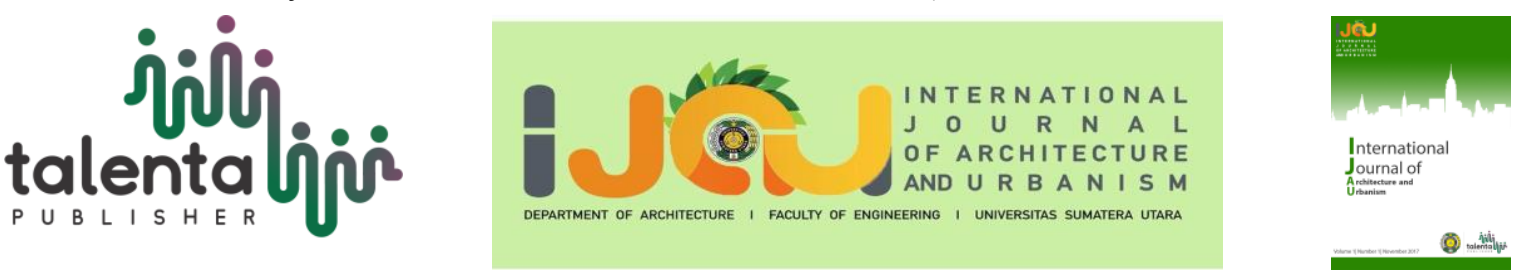

\title{
Designing Life Skill School in Nelayan Seberang Village with Ecological Architecture Approach
}

\author{
Ulfatun Fitri Kusumah ${ }^{1 *}$, Rudolf Sitorus ${ }^{1}$ \\ ${ }^{I}$ Department of Architecture, Faculty of Engineering, Universitas Sumatera Utara, Medan, Indonesia
}

\begin{abstract}
This journal is essential for social, education, and economical in Nelayan Seberang Village. It is about difficult access to schools, low-interest in learning, and economic problems that are part of the factors causing the low level of education of the peoples of Nelayan Seberang Village. The aim is to make it easier for the fishing village community to access educational facilities and increase the level of education of Nelayan Seberang Villagers. The method used in site selection is done through a discussion of primary data. Data sources that directly provide data to data collectors, and secondary data, that is data that does not directly provide data to researchers, through other people or analyzed documents and concluded. The result of the methodology used is Procurement of Life Skills Schools is a practical solution to these problems. Students invited to explore the potential around, manage it, and at the same time, market their products in one place. The ecological architecture applied to this building in such a way that the building can sustain in areas affected by tides and at the same time can reduce negative impacts on the environment. The school buildings designed to friendly to the villagers of Nelayan Seberang Village. So that it can attract peoples to come to school. This is useful to increase the interest in the education of Nelayan Seberang Villagers.
\end{abstract}

Keyword: ecology, school, village

Received 10-01-2020 | Revised 01-02-2020 | Accepted 11-02-2020

\section{Introduction}

The current condition of fishers in Indonesia is still marginalized, especially in Medan. They are rarely getting a higher education, on average, only up to junior high school level. The fishing village community considered that there was no need to go to school. They assume, school or not, they still will be fishermen [1]. There are also the daughters of the fishermen, as is the fate line, they are also directly prepared to be householders. The lack of availability of educational facilities also worsens the low-level of community education in the Nelayan Seberang Village. So far, there is only one kindergarten and one elementary school as the educational facility in

*Corresponding author at: Department of Architecture, Faculty of Engineering, Universitas Sumatera Utara, Jalan Perpustakaan Gedung J07, Medan 20155, Indonesia

E-mail address: ulfa.f.k@gmail.com

Copyright $@ 2020$ Published by Talenta Publisher, 
Nelayan Seberang Village. To get further education like a junior or senior high school, they must first cross to Medan Belawan, District City.

Fishers become a group of impoverished people who live in rich countries. The geographical location of the Nelayan Seberang Village, which is in the coastal area, makes them have abundant natural resources. The Life Skills School designed to be a place for educational activities that teaches the community to manage the potentials of natural resources to be sustained and even increase in quality and quantity so that they can help to improve the economic ability of the community in Nelayan Seberang Village.

\section{Literature Review}

Life skills education is non-formal education that aims to improve the skills, knowledge, and attitudes of students in certain occupations/businesses by their talents, physical and mental development interests and environmental potential, so they can work or to be independent which can be used as asset to improve the quality of their life [2].

Ecology is a science of interaction between all types of living things and their environment. Derived from Greek Oikos is household or way of residence, and Logos is science or scientific. So that ecology can be defined as a science that studies the mutual relations between living things and their environment [3].

Theme's interpretation done by applying the principles of ecological architecture. According to Heinz Frick, several ecological building principles include adaptation to the local natural environment, Saving non-renewable natural energy sources, Maintaining environmental resources (air, soil, water), Maintaining and improving natural circulation, Reducing dependency to the central system of energy (electricity, water) and waste (wastewater and garbage), the possibility of residents to produce their own daily needs. Utilize natural resources around the planning area for building systems, both related to building materials and for building utilities (energy sources, water supply) [3].

\section{Methodology}

The method used in site selection done through discussion of primary data, namely data sources that directly provide data to data collectors, and secondary data, namely data that does not directly provide data to researchers, for example, research must go through people others or search through documents, which are analyzed and concluded [4].

Determine a design concept through the background and problems that occur, both from inside or outside the design location. The method in question is (1) Data collection in the form of background data, goals, and problems related to design. Thus this method carried out studies 
related to Concept approach, sensitive to the design location, Looking for applicable standards and regulations related to design. (2) Analysis of Design so that analysis produced based on standards, regulations, and existing designs, thus obtained considerations to make a design. The analysis in question is form analysis, analysis of functions, aesthetic analysis, analysis of the environment, (3) design concepts. Concepts created through user needs, the environment, analysis and studies that have done, problems found and solutions obtained, and so on.

\section{$4 \quad$ Result and Discussion}

Kampong Nelayan Life Skill School is an informal school that is equivalent to junior and senior high schools with the addition of the life skills curriculum in Nelayan Seberang Village. This school aims to provide knowledge, work skills, that have adapted to local potentials and the ability to work together with students so that they have the courage and willingness to face life and life problems following the natural and social conditions of the communities in which they located.

The project located in Nelayan Seberang Village, Hamparan Perak, Deli Serdang Regency. The project site is a 3.6-hectare mangrove forest with swamp topography that included in affected by tides area. The highest tide height is 2.8 meters above sea level (Figure 1).

On the north side, the site bordered by mangrove forest, on the east, is bordered by mangrove forests, and the Malacca Strait, on the south, is bordered by the Belawan River and on the west, is bordered by the settlement of the Nelayan Seberang Village (Figure 2).

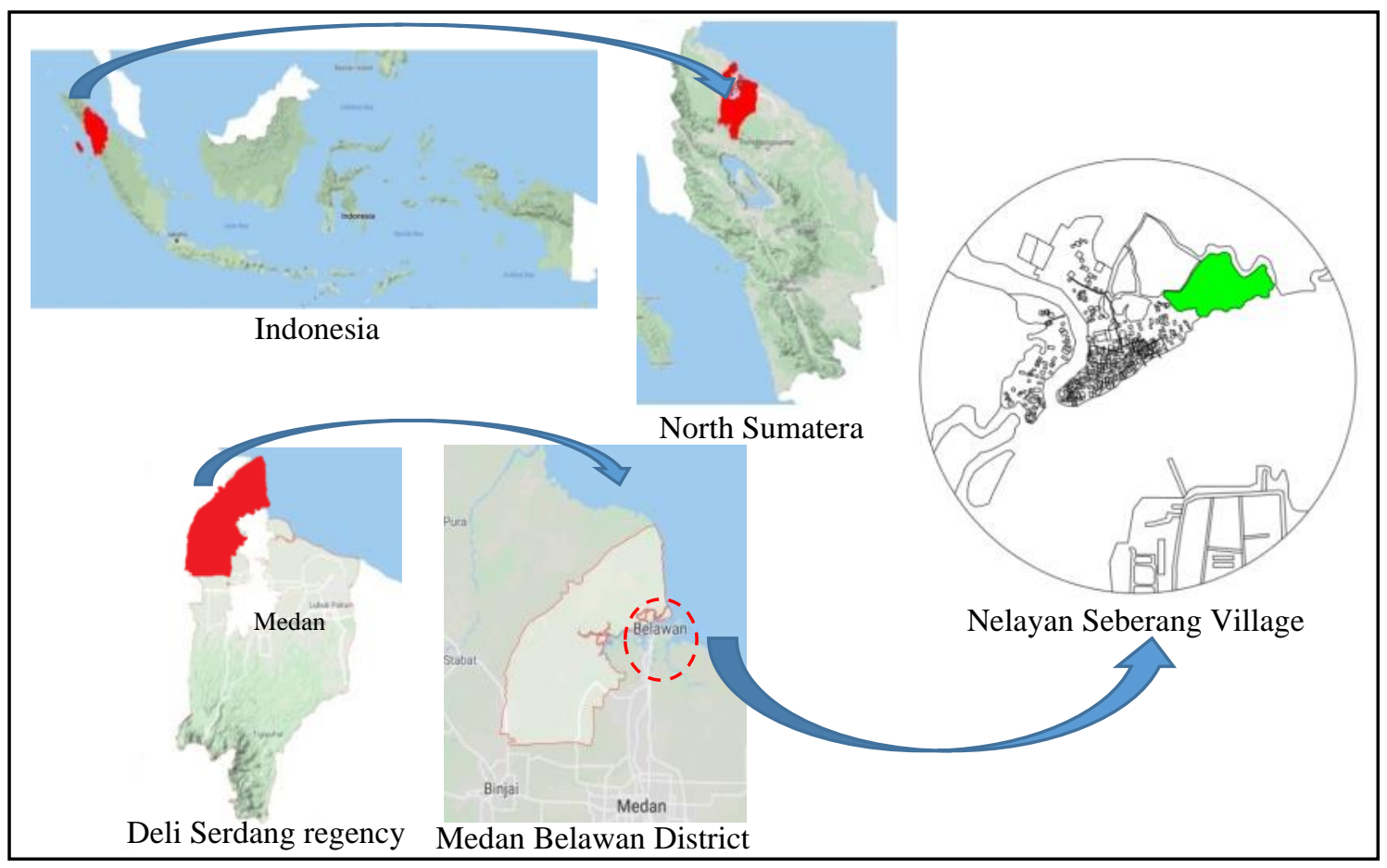

Figure 1 Site location 


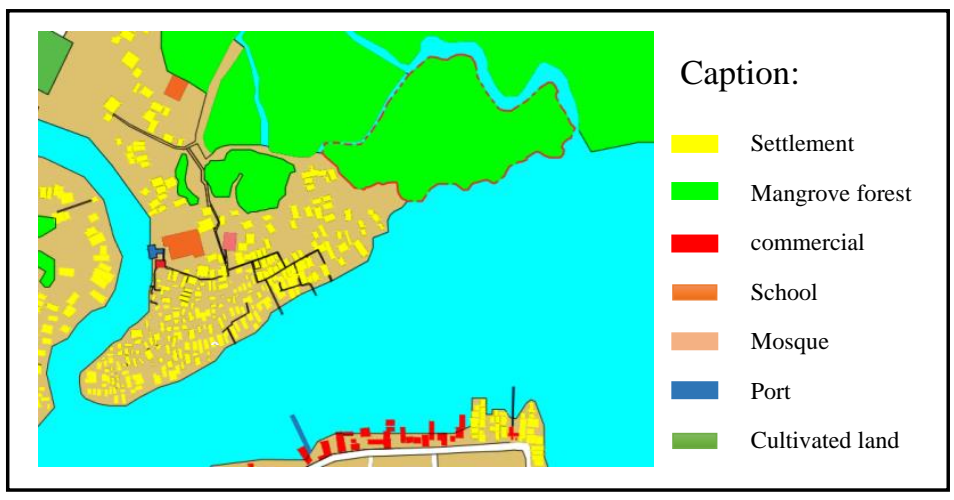

Figure 2 Design Site and the Environment

Mangrove forests are a natural barrier to the effects of ocean waves. This condition is a consideration for creating designs that keep the environment as natural as possible on purpose to maintain it's natural function. The project site is also an area affected by tides so that it requires different handling from the general building designs.

The architectural approach applied to the building is the ecological architecture. It divided into the application of concepts on the physical aspects and social aspects of the building. In the physical aspect ecological architecture are applied by the use of natural building materials such as sea-resin wood, bamboo, fibers and pumice, wastewater treatment before being discharged into the environment, minimizing the use of electrical energy for lighting and airing, and using stilt house concept to avoid flooding during high tides.

The concept of ecology in the social aspect of buildings applied by making the building an open place for all people. School buildings designed without physical boundaries that separate school buildings from residential areas. Society is free to use public functions from schools such as the field, hall, mushallah, and library. This concept aims to make school attendance more easily accepted by the community and be able to attract asking the children of Nelayan Seberang Villages to attend school.

The school designed gateless so that it is freely accessible and creates the impression of a school building that integrated with the village. The schoolyard can function as a children's playground or a gathering place of Nelayan Seberang Villagers at any time (Figure 3).

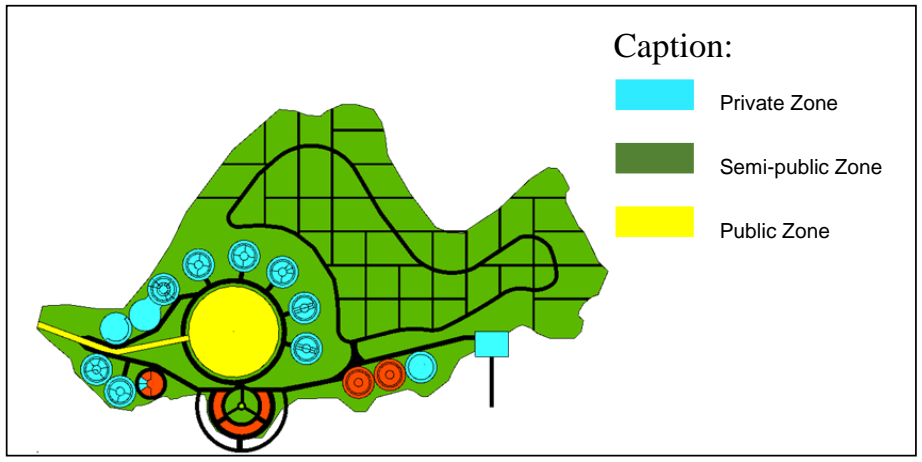

Figure 3 Concept 
The mass of the building oriented towards the south, which directly faces the below sub-district on the other side of the river. The part that looks directly from across the site designed to be more attractive. An attractive design can show the existence of schools and attract the curiosity of people to come.

Based on the analysis, two entrances made into the building. The first entrance is the western gate, which is the entrance of people who come from the village. Second is the southern gate, which is the entrance for people who come by boat. At the southern gate, the dock is placed at the very front and protrudes towards the river. The pier divided into two: the dock for school visitors and tourists and the dock for the ship's automotive workshop (Figure 4).

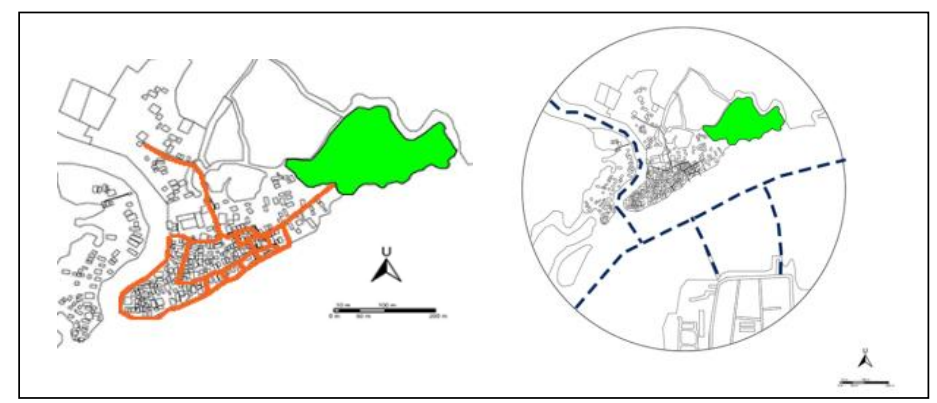

Figure 4 Circulation Analysis

The node of the pedestrian path that becomes the meeting point of pedestrian from the western gate and pedestrian from the southern gate has a larger width. Private and semi-public pedestrian path has a taller height than the public pedestrian path to gives the impression of a different zone (Figure 5).

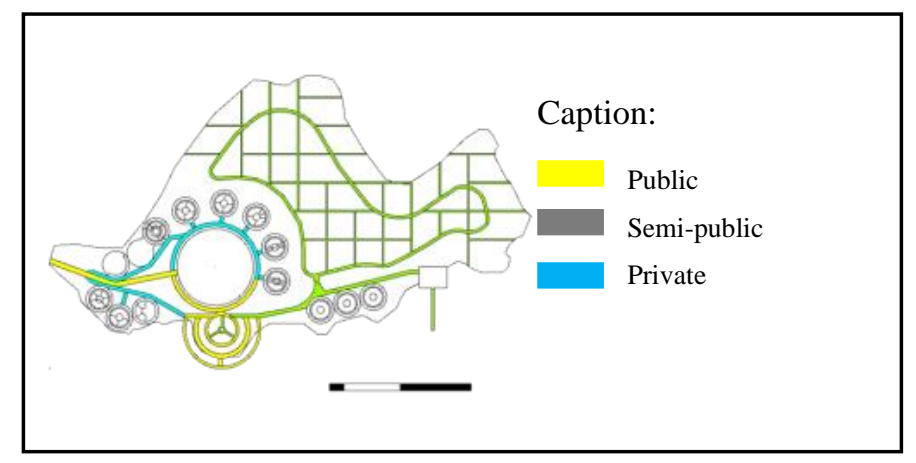

Figure 5 Circulation Concept

Vegetation found on the site is entirely mangrove plants. Vegetation designed not only as a part of outer space but also become part of the inner space of the school building. There are two groups of vegetation, vegetation as greenery and vegetation as cultivated plants (Figure 6). 


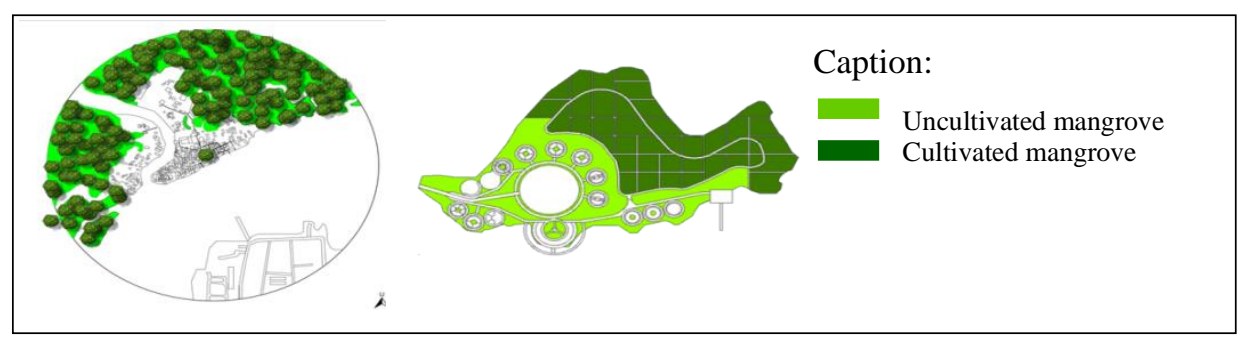

Figure 6 Vegetation concept

The tourism zone highlighted in the front area to be a point to attract tourist's attention and can see from across the river. The management zone still placed in the front area to easily accessed by the guest. Educational zones that need a quiet environment place in the middle and rear areas. The support zone placed on the edge of the site area. Service zones placed in position according to the function (Figure 7).

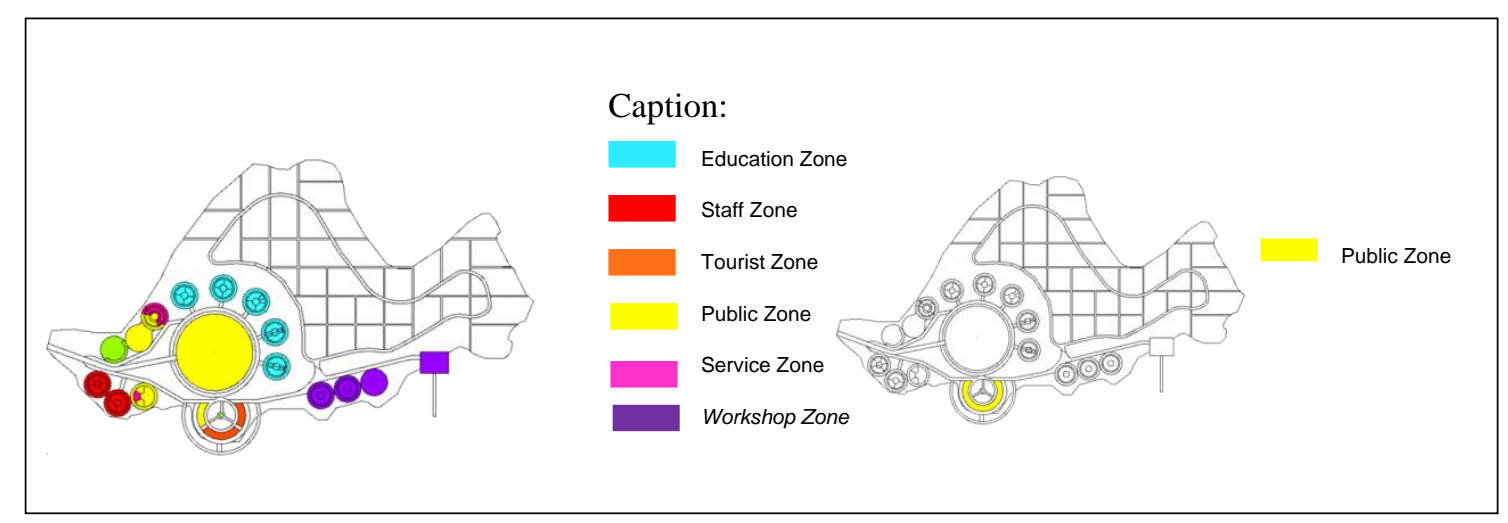

Figure 7 Zoning Concept

The mass of the building designed with a radial pattern. The radial pattern is a combination of two patterns, centralized pattern and linear pattern. In the radial pattern, a central space becomes the reference for linear space organizations [5]. This pattern gives the impression of being flexible but still has a supervisory function for each room. The school field becomes the central space of the mass-forming pattern. The mass of each building or room designed to follow its function with a circle as the basic shape.

The building has a higher mass to make it looks more prominent than the surrounding buildings. The southernmost building mass, which is a mass that looks directly from across the river, designed more catchy to attracts people's curiosity to come. There is a lighthouse that makes it looks more attractive (Figure 8).

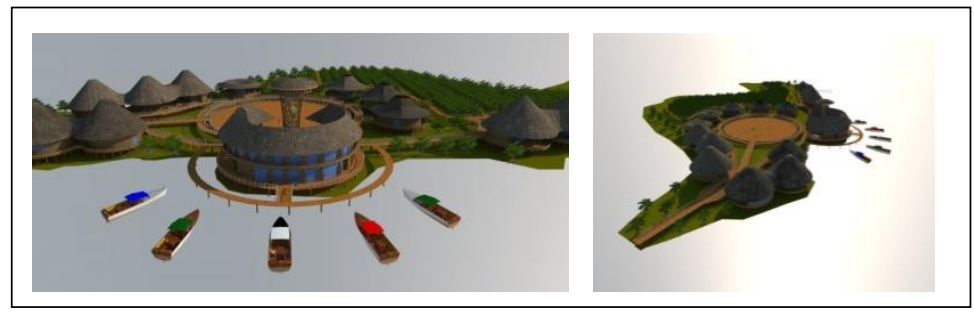

Figure 8 Mass 
The exterior of the building designed to look as natural as possible. Most of the materials used in facade are natural materials such as bamboo and fibers. Facade material only uses a coating to keep it durable (Figure 9).

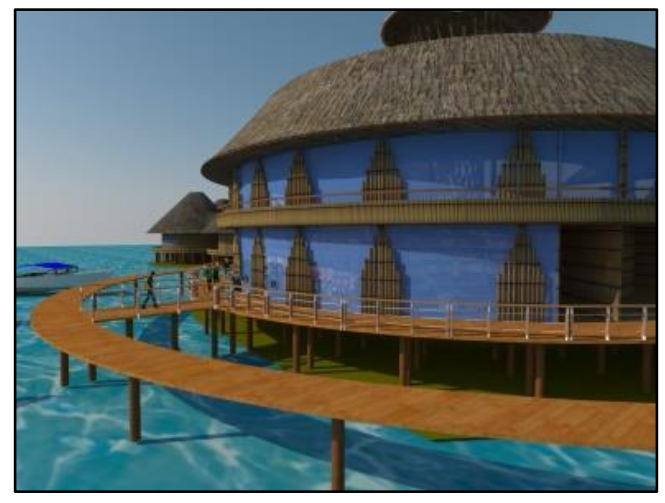

Figure 9 Facade

Spaces designed with a circular pattern. At each Center of a circular pattern in each room is given an inner court containing vegetation. The inner court serves as a way for natural light to enter the room. Wide openings and cross ventilation are applied to the building to create smooth air circulation. Spaces such as classrooms, halls, and art workshop rooms are designed without walls so that they are more integrated with nature (Figure 10).
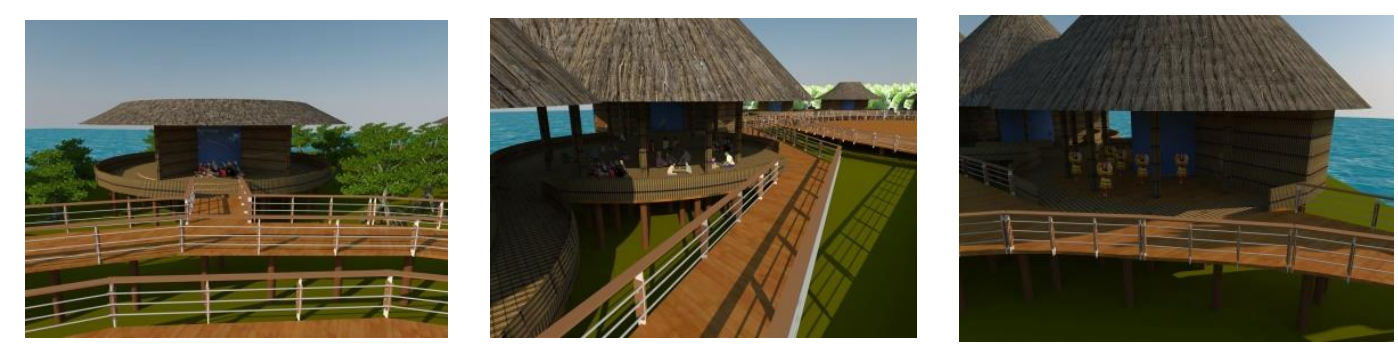

Figure 10 Interior

Generally, the structure system that applied is the structure of stilts houses with bamboo construction. Bamboo construction choosen because it has a strength that is not inferior to steel. $12 \mathrm{~mm}$ bolts and fibers used to join between bamboo. Bolt joints create a construction that able to move along the direction of an earthquake vibration, therefore reducing the risk of building collapse.

Innovations did on the foundations and walls construction. In foundation construction, The nature of bamboo, which cannot directly be exposed to water, makes sea wood resin foundation an option. Sea resin wood starts at the base of the foundation up to $50 \mathrm{~cm}$ above the highest level of the tide. Sea resin wood and bamboo connected using nuts and iron plates (Figure 11). 


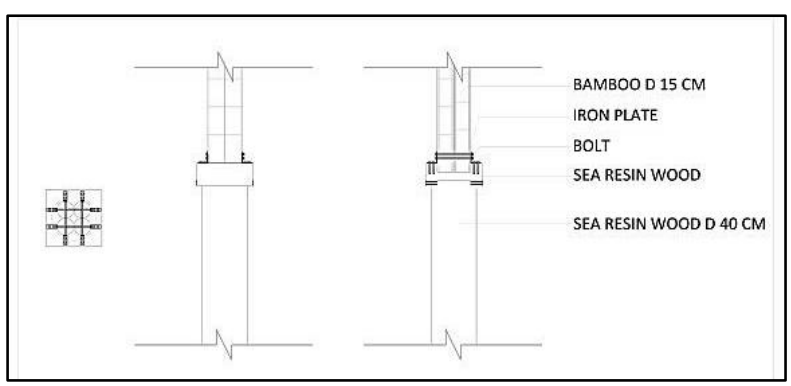

Figure 11 Foundation detail

In the wall construction, the walls use bamboo with a $6 \mathrm{~cm}$ diameter. Bamboo is arranged vertically to form a wall. Walls in certain rooms such as laboratories, worship rooms, and offices that require a quiet condition room are designed with pumice stones between two bamboo walls on purpose to reduce noise (Figure 12).

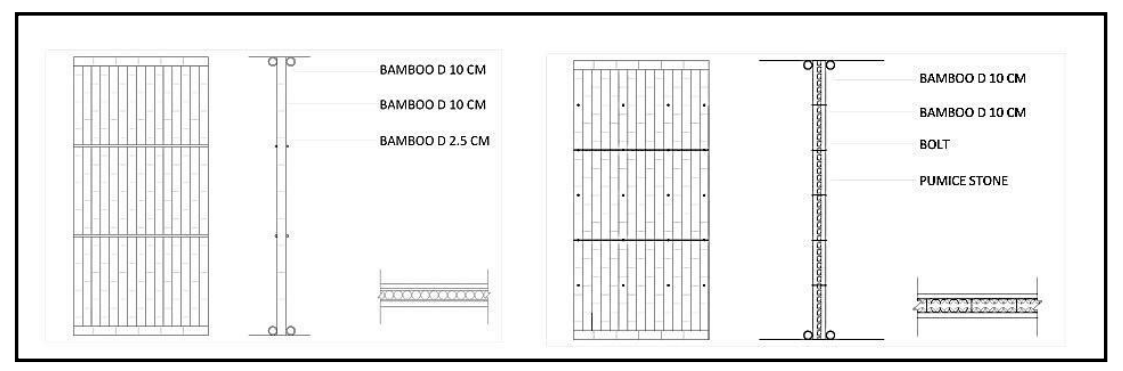

Figure 12 Wall detail

There are two innovations of the utilitiy system made in this design. Installation of clean water and Installation of grey and black water. Clean water sourced from bore wells. Water from the bore wells is pumped and flowed to the first storage tank, and then flowed to the filter tank that is containing, sand, fibers, and charcoal then flowed again to the second storage tank before being distributed to the toilets (Figure 13).

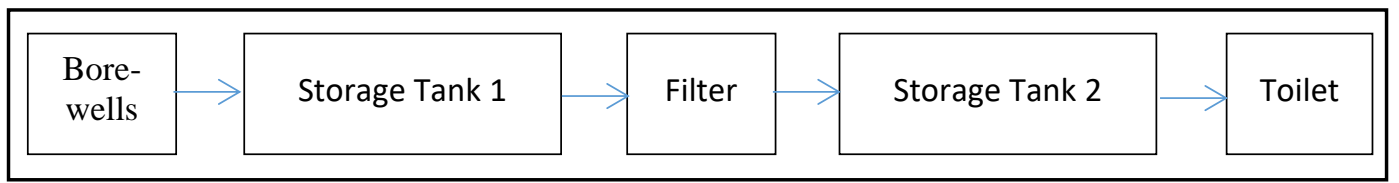

Figure 13 Schematic clean water installation

The concept applied to wastewater treatment, which is wastewater from the closet directed to the BIOFIL BF 08 waste treatment unit through a 3-inch diameter pipe to the inlet and outlet points placed above the maximum tide level. After going through the processing unit, the waste flows to the Sanitary floating Garden. Sanitary floating garden contains water jasmine which planted on coconut coir, Galam wood, and plastic-made fishnets as a growing medium (Figure $14)$. 


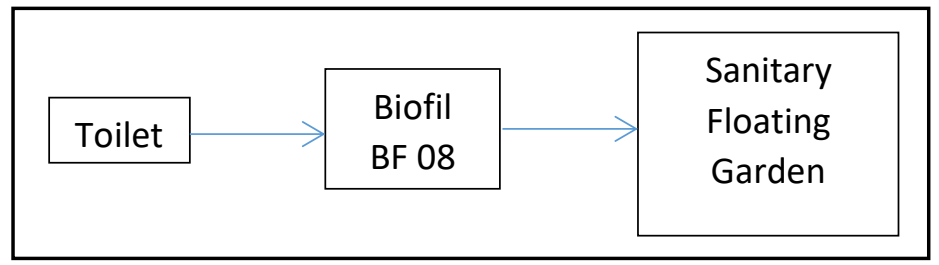

Figure 14 Schematic dirty water treatment

\section{Conclusion}

The Design of Life Skills School, which located in the Nelayan Seberang Village, aims to provide an option of solutions about the condition of the fishermen community in Belawan whose still marginalized. The Nelayan Seberang Village Life Skills School, it is expected to facilitate access to the Nelayan Seberang Village community to get a higher level of education. Through school education, the fishing community will learn and then be able to process, maintain, and utilize the potential of natural wealth more optimally. So it can raise the standard of living of the people of Nelayan Seberang Village.

Ecological architecture applied through social aspects and physical aspects. Application of social aspects done by designed the school buildings without boundaries. This design makes the building integrated with the residential areas. It makes the school easily accepted by the villagers and can attract the interests of the children of the Nelayan Seberang Village to go to school. Public functions are also open to the public so that the school building does not only give benefits to those who school but also to all villagers.

The principles of ecological architecture applied to the physical aspects of school building make the school buildings sustainable even though it located in an area with quite extreme natural conditions. The application of ecological principles can also help to reduce the negative impact of school buildings on the surrounding environment. This eco-friendly building design also indirectly educates and increases people's sensitivity to environmental cleanliness and nature conservation.

\section{Acknowledgment}

This research is about to design a school that is environmentally friendly and integrates with the social conditions of the community in Nelayan Seberang Village, Belawan. The author thanks The Department of Architecture at North Sumatera University for the guidance in writing this research.

\section{REFERENCES}

[1] Cerita Medan. (2015, May) Cerita Medan. [Online]. https://ceritamedan.com/2015/05/masyarakat-kampung-nelayan.html 
[2] Francis D.K. Ching, Arsitektur Bentuk, Ruang dan Susunannya. Jakarta: Penerbit Erlangga, 1999.

[3] Heinz Frick, Dasar-Dasar Eko-Arsitektur. Bambang Suskiyatno,penerjemah. Yogyakarta: Penerbit Kanisius, 1998.

[4] Sugiyono, Metode Penelitian Kuantitatif, Kualitatif dan $R \& D$. Bandung: Penerbit Alfabeta, 2006.

[5] Menteri Pendidikan dan Kebudayaan Republik Indonesia. (2010) Peraturan Pemerintah Republik Indonesia Nomor 17 Tahun 2010 Tentang Pengelolaan dan Penyelenggaraan Pendidikan. 